\title{
Breast Lipoma
}

National Cancer Institute

\section{Source}

National Cancer Institute. Breast Lipoma. NCI Thesaurus. Code C4647.

A benign, mesenchymal neoplasm that arises from the breast. It is surrounded by a thin capsule and composed of mature adipose tissue cells. Atypia is absent. 